\title{
Irrigation of arugula cultivars in the region of Zona da Mata Mineira
}

\section{Irrigação de cultivares de rúcula na região da Zona da Mata Mineira}

\author{
Caio César Silva Alvarenga Correia ${ }^{1}$; Fernando França da Cunha ${ }^{2 *}$; \\ Everardo Chartuni Mantovani²; Derly Jose Henriques da Silva ${ }^{3}$; \\ Santos Henrique Brant Dias ${ }^{1}$; Thallita de Sousa Ferreira ${ }^{4}$
}

\begin{abstract}
The region of the Zona da Mata of Minas Gerais stands out in the production of vegetables. To achieve the success in this activity, it is important to choose suitable cultivars and apply irrigation correctly. This study aimed to determine the optimum irrigation depth and evaluate new commercial arugula cultivars in the Zona da Mata of Minas Gerais. The cultivation was carried out in a greenhouse during three cycles with periods of 33 (January 11, 2016 to February 12, 2016), 36 (March 1, 2016 to April 5, 2016), and 36 (April 12, 2016 to May 17, 2016) days. The experimental design was a randomized complete block design with five replications, five irrigation depths $(50,75,100,125$, and $150 \%$ of the crop evapotranspiration-ETc) in the plots, and three arugula cultivars (Antonella, Cultivada, and Folha Larga) in the subplots. A drip irrigation system was used. The parameters evaluated were root depth, root fresh mass, plant water potential, leaf temperature, number of commercial leaves, total number of plants, fresh shoot mass, and water use efficiency. Arugula cultivars did not present differences in their agronomic characteristics. An irrigation depth of the 50\% ETc is recommended if the soil moisture is under the field capacity at the beginning of the arugula cycle.
\end{abstract}

Key words: Euruca sativa L. Horticulture. Irrigation management.

\section{Resumo}

A região da Zona da Mata mineira se destaca na produção de hortaliças. Para alcançar sucesso nesta atividade, é importante escolher cultivares adequadas e aplicar corretamente a irrigação. Objetivou-se determinar a lâmina ótima de irrigação e avaliar novas cultivares comerciais de rúcula na Zona da Mata de Minas Gerais. O cultivo foi em ambiente protegido durante três ciclos com períodos de 33 (11/1 à 12/2/2016), 36 (1/3 à 5/4/2016) e $36(12 / 4$ à 17/5/2016) dias. O delineamento experimental foi em blocos ao acaso em esquema de parcelas subdivididas, com cinco repetições, tendo nas parcelas cinco lâminas de irrigação $(50 ; 75 ; 100 ; 125$ e 150\% da evapotranspiração da cultura-ETc) e nas subparcelas três cultivares de rúcula: Antonella, Cultivada e Folha Larga. O sistema de irrigação foi gotejamento. Os parâmetros avaliados foram: profundidade e massa fresca de raízes, potencial de água na planta,

1 Discentes de Mestrado, Universidade Federal de Viçosa, Departamento de Engenharia Agrícola, UFV/DEA, Viçosa, MG, Brasil. E-mail: caio_ufv@yahoo.com.br; santosdiasagro@gmail.com

2 Profs., Drs., Departamento de Engenharia Agrícola, UFV/DEA, Viçosa, MG, Brasil. E-mail: fernando.cunha@ufv.br; everardo@ ufv.br

3 Prof. Dr., Departamento de Fitotecnia, UFV/DFT, Viçosa, MG, Brasil. E-mail: derly@ufv.br

4 Discente de Graduação, UFV/DEA, Viçosa, MG, Brasil. E-mail: thalitadesferreira@gmail.com

* Author for correspondence 
temperatura foliar, número de folhas comerciais, número total de plantas, massa fresca da parte aérea e eficiência do uso da água. As cultivares de rúcula não apresentaram diferenças em suas características agronômicas. Recomenda-se irrigar a cultura da rúcula com lâmina de $50 \%$ da ETc, desde que, no início do ciclo o solo esteja na capacidade de campo.

Palavras-chave: Euruca sativa L. Horticultura. Manejo da irrigação.

\section{Introduction}

Arugula (Euruca sativa L.), also known as Persian mustard, is a fast-growing vegetable that has a spicy taste and a pleasant and accented smell. According to Borges et al. (2014), arugula originates from the Mediterranean region and is very popular in regions of Italian colonization in Brazil because its introduction in the country is due to the Italian immigration. This vegetable is rich in potassium, sulfur, iron, and vitamins A and C (FREITAS et al., 2017).

There are no major site constraints for arugula cultivation (COSTA et al., 2011), but it is expected that greater commercial advantages will be achieved by implanting it near urban centers using family farming. The Zona da Mata region has a large number of family properties in which arugula is an important cultivation option. The potential of arugula production in these establishments is high and needs a better technical basis for their viability.

However, the existing literature on the agronomic and economic performance of vegetables such as arugula in the Zona da Mata of Minas Gerais is still insufficient and its use is still based on the empirical experience of producers. Therefore, there is a need to evaluate new cultivars that are in the market, allowing increases in productivity. Many farmers, not knowing about this fact, insist on using the same materials that their ancestors used, making the crop less productive and discouraging the activity.

In addition to choosing the right variety, the success in the production of vegetables depends on the use of irrigation to provide total or supplement the water needs of the crop. The use of irrigation systems in horticulture is justified because the irregularity in the pluvial regime becomes restrictive to the agricultural development since even during rainy seasons there are periods of water deficit. The evapotranspiration of vegetables usually exceeds rainfall, so the adequate distribution of water in an artificial way through irrigation has been the guarantee to produce as planned, without the lack of rain changes the productivity and profitability indexes previously established (CUNHA et al., 2013). In addition, when cultivation is protected, irrigation becomes even more important.

Irrigation provides benefits to arugula production and should be performed at an appropriate time and quantity. Thus, there is a need for water management to be performed adequately and the amount of water that must be supplied to arugula crop needs to be determined. When there is no management, the application of irrigation may occur in excess or deficit. The application in deficit can compromise the productivity and quality of arugula. Similarly, the excess of water can lead to the appearance of diseases and reduction of quality, making the irrigation system unfeasible.

Among the irrigation systems, drip irrigation has been successfully adopted for crops since it presents a higher water use efficiency, lower energy consumption, allows the use of fertigation, and reduces the incidence of diseases by providing less leaf wetness than sprinkling (BATISTA et al., 2009). Several authors have recommended the drip irrigation system in arugula cultivation (MOLINE et al., 2015, FREITAS et al., 2017; CUNHA et al., 2018).

Considering that the water balance in the Zona da Mata does not allow the cultivation of arugula in the rainfed system and the scarcity of scientific work with this crop, the response of cultivars to irrigation 
needs to be studied in this region. Thus, the aim of this research was to determine the optimal irrigation depth and evaluate new commercial arugula cultivars in the Zona da Mata of Minas Gerais.

\section{Material and Methods}

The experiment was carried out at the research station of the Federal University of Viçosa (UFV), located in the city of Viçosa, MG. The experimental area is located at the latitude $20^{\circ} 45^{\prime} \mathrm{S}$ and longitude $42^{\circ} 52^{\prime} \mathrm{W}$, with an altitude of $648 \mathrm{~m}$.

The soil in the area is classified as a Red-Yellow Latosol according to Dos Santos et al. (2013).
Before the installation of the experiment, soil samples were collected in the 0-15 and $15-30 \mathrm{~cm}$ layers, and soil physical-hydric analyses (Table 1) were performed at the Laboratory of Soil Physics of the UFV. Soil bulk densities were obtained following the recommendations of Embrapa (2011). Water contents equivalent to the field capacity were obtained by the basin method (BERNARDO et al., 2006) and the permanent wilting points were obtained by means of water retention curves in the soil using the Richards extractor. For that, the tension of $1,500 \mathrm{kPa}$ was used as that equivalent to the permanent wilting point.

Table 1. Results of the physical-water analysis at different soil layer. Viçosa-MG, DEA-UFV, 2016.

\begin{tabular}{|c|c|c|c|}
\hline Soil layer & $\mathrm{FC}^{1}$ & $\mathrm{PWP}^{2}$ & $\mathrm{BD}^{3}$ \\
\hline$\cdots \cdots \cdots \cdot \mathrm{cm}^{\cdots \cdots \cdots \cdots}$ & \multicolumn{2}{|c|}{ 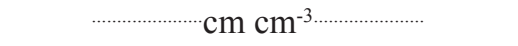 } & $\cdots \cdots \mathrm{g} \mathrm{cm}^{-3} \ldots \ldots$ \\
\hline $0-15$ & 0.4474 & 0.2656 & 1.24 \\
\hline $15-30$ & 0.4482 & 0.2739 & 1.27 \\
\hline
\end{tabular}

${ }^{1}$ Humidity equivalent to the field capacity by the basin method; ${ }^{2}$ Permanent wilting point; ${ }^{3}$ Soil bulk density.

Soil tillage was conducted in the greenhouse area with a rotary hoe and then one-meter-wide crop beds were prepared manually using hand hoes. Soil chemical attributes were determined before the first cultivation and were carried out at the Laboratory of Soil Chemistry of the UFV (Table 2). No fertilization was recommended in the area because the nutrient contents were adequate for the arugula crop (SEDIYAMA et al., 2007).

Table 2. Results of soil chemical analysis. Viçosa-MG, DEA-UFV, 2016.

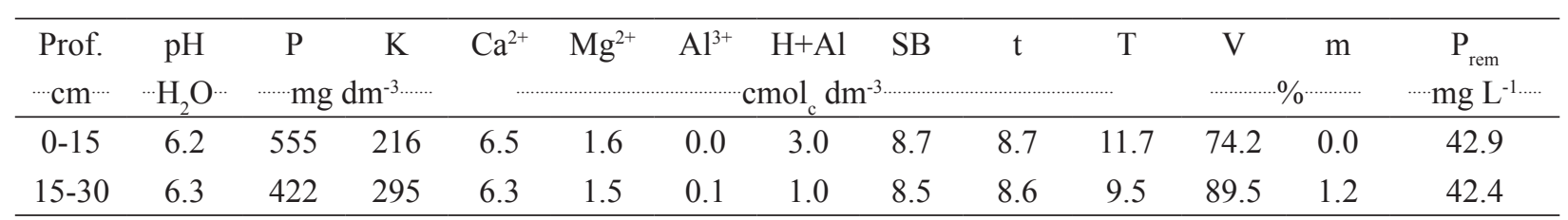

Available P and $\mathrm{K}$ extracted with Mehlich I; Ca, $\mathrm{Mg}$ and $\mathrm{Al}$ extracted with $\mathrm{KCl} 1 \mathrm{~mol} \mathrm{~L}^{-1}$; Potential acidity at pH 7.0 extracted with calcium acetate $0.5 \mathrm{~mol} \mathrm{~L}^{-1}$.

A direct sowing was carried out following the spacing of $0.2 \mathrm{~m}$ between rows and $0.05 \mathrm{~m}$ between plants. Thinning was performed 15 days after sowing (DAS), maintaining a spacing of 0.1 $\mathrm{m}$ between plants. Arugula crop was cultivated in the greenhouse during three cycles with periods of 33 (January 11, 2016 to February 12, 2016), 36 (March 1, 2016 to April 5, 2016), and 36 (April 12, 
2016 to May 17, 2016) days. The greenhouse had a total area of $240 \mathrm{~m}^{2}$ ( $8 \mathrm{~m}$ wide and $30 \mathrm{~m}$ long), with sides covered with a polyethylene wire mesh, ceiling covered with a $90 \mu \mathrm{m}$ blue plastic, and a $20 \%$ shading screen installed under the roof inside the greenhouse.

The experimental design was a randomized complete block design with five replications, five irrigation depths in the plots, and three arugula cultivars in the subplots. Sample units were composed of plots of $0.8 \mathrm{~m}$ wide and $1.0 \mathrm{~m}$ long, with a total area of $0.8 \mathrm{~m}^{2}$, totaling 40 plants per experimental unit.

The used arugula cultivars were Antonella (Isla), Cultivada (Isla), and Folha Larga (Feltrin). The irrigation depths consisted of the replacement of $50,75,100,125$, and $150 \%$ of the crop evapotranspiration (ETc).

The drip irrigation system was operated by gravity. The drip tapes (Amandi model from Petroisa manufacturer) had $0.016 \mathrm{~m}$ in diameter. The spacing between the drip tapes was $0.4 \mathrm{~m}$, which allowed the irrigation of two rows of plants per lateral row. The emitters (drippers) operated with a service pressure of $100 \mathrm{kPa}$ ( 10.2 m.c.a.), applying an approximate flow of $1.2 \mathrm{~L} \mathrm{~h}^{-1}$, and spaced $0.2 \mathrm{~m}$ apart. For the differentiation between treatments with irrigation depths, the use of line-in connectors with registers was used. According to the time required to apply the different irrigation depths, the registers were opened or closed and different slides were obtained in the treatments.

The irrigation schedule was fixed for each crop stage, being in the first stage of two days and the later stages of three days. The net irrigation depth by the treatment with $100 \%$ ETc water replenishment was defined as a function of climate parameters, irrigation system, plant, and soil (Equation 1), representing the actual water requirement of the crop.

$$
N I D=\sum_{\text {dia } 1}^{i} \text { ETo } K_{C} K_{S} K_{L}-\mathrm{P}
$$

where NID is the net irrigation depth, mm; ETo is the reference evapotranspiration, $\mathrm{mm} \mathrm{d}^{-1} ; \mathrm{K}_{\mathrm{C}}$ is the crop coefficient, dimensionless; $\mathrm{K}_{\mathrm{S}}$ is the soil moisture coefficient, dimensionless; $\mathrm{K}_{\mathrm{L}}$ is the location coefficient, dimensionless; and $\mathrm{P}$ is the effective precipitation in the period, $\mathrm{mm}$.

The effective precipitation is that used directly by the crop (BERNARDO et al., 2006), being the experiment conducted in a greenhouse whose value corresponded to zero throughout the experimental period.

The Penman-Monteith methodology (ALLEN et al., 1998) was used to estimate the reference evapotranspiration (ETo). The daily meteorological data for ETo estimation were collected from an automatic weather station E 4000 installed inside the greenhouse. The parameters collected were air temperature $\left({ }^{\circ} \mathrm{C}\right)$; relative humidity $(\%)$, and solar radiation $\left(\mathrm{MJ} \mathrm{m}^{-2}\right)$. Wind velocity at $2 \mathrm{~m}$ height was assumed to be $0.02 \mathrm{~m} \mathrm{~s}^{-1}$. The variations of the daily meteorological elements in the three periods of arugula cultivation are presented in Figure 1.

The applied crop coefficients were 0.7 and 1.0 for stages I and III, respectively. For stage II, a linear weighting was used between the end of stage I and the beginning of stage III. The duration of stages I and II were 10 days each and stage III lasted from the 20th day to harvest. Soil moisture coefficient and location coefficient were calculated according to Equations 2 and 3, respectively.

$$
\begin{aligned}
& K_{S}=\frac{\ln (R A W+1)}{\ln (T A W+1)} \\
& K_{L}=0.1 \sqrt{P}
\end{aligned}
$$

where $\mathrm{K}_{\mathrm{S}}$ is the soil moisture coefficient, dimensionless; RAW is the readily available water, $\mathrm{mm}$; TAW is the total available water, $\mathrm{mm}$; $\mathrm{K}_{\mathrm{L}}$ is the location coefficient, dimensionless; and $\mathrm{P}$ is the highest value between the percentage of wet or shaded area, $\%$. 
The NID value was corrected according to the irrigation system efficiency, defining the total irrigation depth (TID) according to Equation 4.

$$
T I D=\frac{N I D}{I E}
$$

where TID is the total irrigation depth, mm; NID is the net irrigation depth, $\mathrm{mm}$; and IE is the irrigation efficiency, decimal.

In localized irrigation systems, application efficiency is of approximately $100 \%$ and the irrigation efficiency is equal to the distribution efficiency to cover adequately an irrigated area of $80 \%$. The uniformity of water distribution was determined using the methodology proposed by Keller and Karmeli (1975). The uniformity coefficient was calculated according to the methodology expressed by the distribution uniformity coefficient (Equation 5).

$$
D U=\frac{X_{25}}{X_{m}}
$$

where DU is the distribution uniformity coefficient, decimal; $\mathrm{X}_{25}$ is the average low-quarter depth of the received water, $\mathrm{mm}$; and $X_{m}$ is the average depth of the received water, $\mathrm{mm}$.

Figure 1. Daily variation of $(A)$ solar radiation $\left(\mathrm{MJ} \mathrm{m}^{-2} \mathrm{~d}^{-1}\right)$, reference evapotranspiration $\left(\mathrm{mm} \mathrm{d}^{-1}\right)(B)$ temperature $\left({ }^{\circ} \mathrm{C}\right)$ and relative humidity. Viçosa-MG, DEA-UFV, 2016.

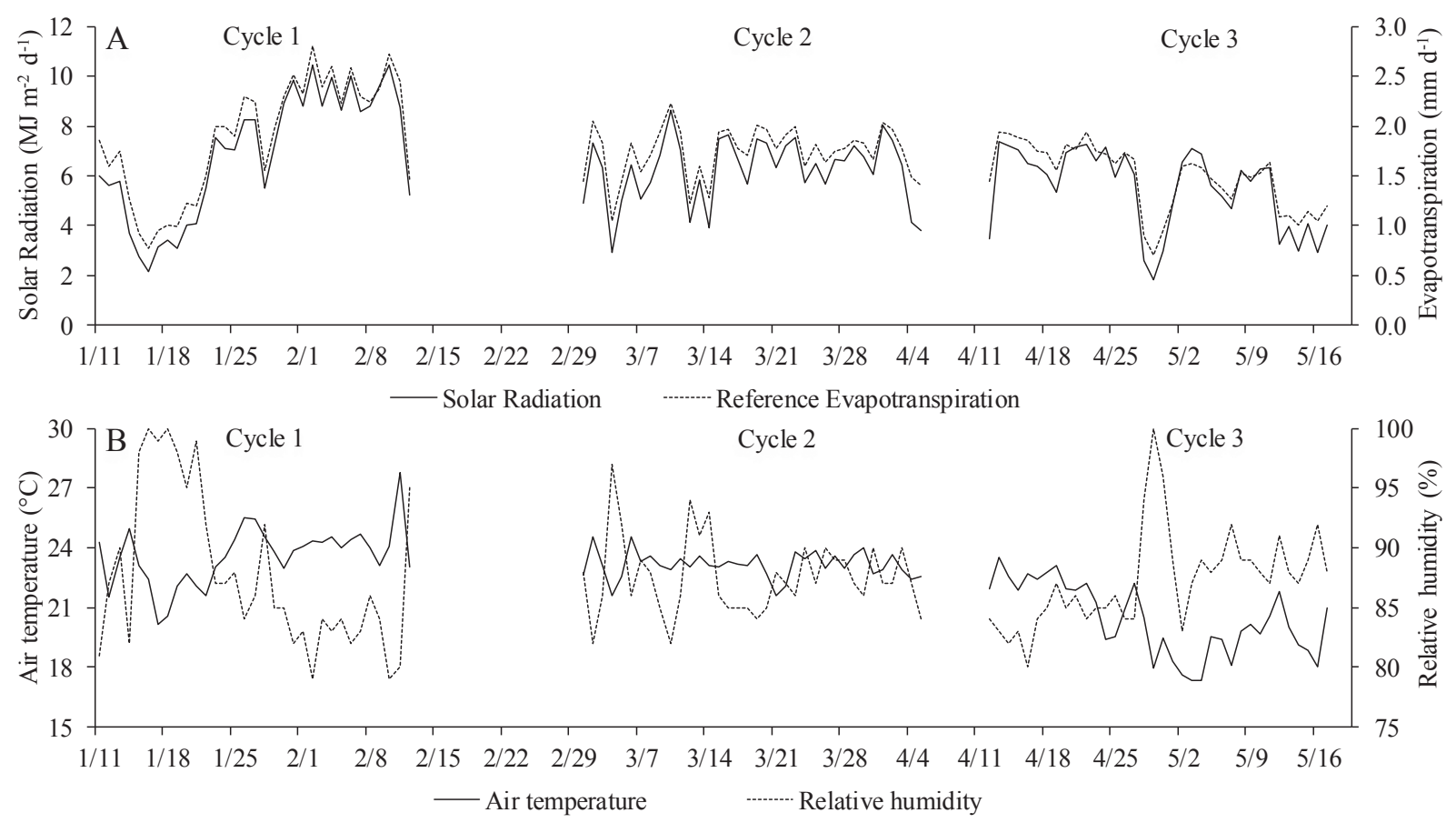

Root depth in cm was obtained by opening a lateral trench to the plants using a hoe. After the removal of the root as deep as possible, the soil adhered to the roots was removed and the plant was taken to measure the distance between the collar and the root end using a $0.1 \mathrm{~cm}$ scale ruler. This analysis was performed in four captive plants previously identified at the beginning of their cycles.
Root fresh mass in $\mathrm{g} \mathrm{pl}^{-1}$ was determined by weighing the roots of each plant.

Plant water potential in $\mathrm{kPa}$ was obtained using the Scholander pump methodology (SCHOLANDER et al., 1965). The measurements were taken between 3:00 a.m. and 6:00 p.m. when the water potential in the plant was maximum. However, the potential replacement is not verified under water stress, 
evidencing some level of water stress caused by the lack of water in the soil. Because the nitrogen gas is dry, a wet paper was used inside the chamber to make the measurement. The analysis was performed on two leaves obtained from two different plants.

Leaf temperature in ${ }^{\circ} \mathrm{C}$ was measured with a digital infrared thermometer by measuring four plants per plot. The evaluations were carried out between 11:30 a.m. and 1:30 p.m., i.e. at moments of the highest insolation to avoid effects in the variations in the time at the moment of the measurement. No measurements were taken when clouds were present.

The number of commercial leaves per plant consisted of the number of leaves that could be marketed per plant, i.e. without damages and with adequate size. The counting was performed in four plants per plot after harvesting.

The total number of plants in $\mathrm{ud} \mathrm{m}^{-2}$ consisted of the total number of plants harvested in each plot. The value referred to plant units in the plots.

Shoot fresh mass in $\mathrm{kg} \mathrm{m}^{-2}$ was obtained by the relationship between the mass of all plants of the plot after the roots were removed and the area of cultivation.

Water use efficiency in $\mathrm{kg} \mathrm{m}^{-3}$ was obtained by the relationship between the commercial productivity of the vegetable in the plot and the amount of water applied.

The three crop cycles did not enter as a source of variation in the analysis of results. The replication of the experiments over time was motivated only for a greater reliability in the results. The data for each cycle of arugula cultivation were submitted to the analyses of variance and regression. The mean comparison was performed using the Tukey's test at $5 \%$ probability. For the quantitative factors, linear and quadratic models were tested. The selection of the model was based on the significance of the regression coefficients by using the t-test at $5 \%$ probability, coefficient of determination $\left(\mathrm{R}^{2}\right)$, and biological phenomena. Simple correlation (r) analyses were performed for all the evaluated parameters and classified as very low $(\mathrm{r}<0.1)$, low $(0.1<\mathrm{r}<0.3)$, moderate $(0.3<\mathrm{r}<0.5)$, high $(0.5<\mathrm{r}<0.7)$, very high $(0.7<\mathrm{r}<0.9)$, and near perfect $(\mathrm{r}>0.9)$ according to Cohen (1988). The statistical analysis was performed using the statistical software Assistat 7.7 (SILVA; AZEVEDO, 2016) and SigmaPlot 11.0 (SYSTAT SOFTWARE, INC., 2008).

\section{Results and Discussion}

The variations of the daily meteorological elements in the three growing periods of the vegetables are shown in Figure 1. Solar radiation (Figure 1A) was higher in the first cycle, presenting a mean value over the entire period of $7.0 \mathrm{MJ} \mathrm{m}^{-2} \mathrm{~d}^{-1}$ and oscillating within a range of 2.2 and $10.4 \mathrm{MJ} \mathrm{m}^{-2}$ $\mathrm{d}^{-1}$, while cycles 2 and 3 presented values of 5.9 and $5.4 \mathrm{MJ} \mathrm{m}^{-2} \mathrm{~d}^{-1}$, respectively. Solar radiation oscillated between 2.7 and $8.6 \mathrm{MJ} \mathrm{m}^{-2} \mathrm{~d}^{-1}$ in the cycle 2 and between 1.9 and $7.4 \mathrm{MJ} \mathrm{m}^{-2} \mathrm{~d}^{-1}$ in the cycle 3. This behavior influenced the values of air temperature (Figure 1B) and reference evapotranspiration (ETo) (Figure 1A).

The average daily air temperature (Figure 1B), as well as the solar radiation, was higher in the first cycle, reaching a mean value of $23.7^{\circ} \mathrm{C}$ and varying within a range of 20.2 and $27.8^{\circ} \mathrm{C}$. For the second cycle, the maximum and minimum temperature was 24.6 and $21.4{ }^{\circ} \mathrm{C}$, respectively, with a mean temperature of $23.0{ }^{\circ} \mathrm{C}$. In the third cycle, the maximum and minimum temperature was 23.5 and $17.4^{\circ} \mathrm{C}$, respectively, with a mean of $20.5^{\circ} \mathrm{C}$.

The mean relative humidity varied slightly between cycles. In the first cycle, the mean value was $88 \%$, while in the cycles 2 and 3 , the values were 87.6 and $87.3 \%$, respectively. The maximum value for the three cycles was $100 \%$, while the minimum values were 33,46 , and $41 \%$ for the cycles 1,2 , and 3 , respectively. The higher values of temperatures coincided with the lower values of relative humidity (Figure 1B) over the three cycles, 
which was expected since the relative humidity variation is inversely related to the air temperature.

The ETo (Figure 1A) was also higher in the first cycle, reaching a mean value of $1.92 \mathrm{~mm} \mathrm{~d}^{-1}$ and varying within a range of 0.77 and $2.80 \mathrm{~mm} \mathrm{~d}^{-1}$. In the second cycle, the mean value was $1.71 \mathrm{~mm} \mathrm{~d}^{-1}$, ranging from 1.04 to $2.23 \mathrm{~mm} \mathrm{~d}^{-1}$. In the third cycle, the mean ETo was $1.48 \mathrm{~mm} \mathrm{~d}^{-1}$, varying between 0.70 and $1.94 \mathrm{~mm} \mathrm{~d}^{-1}$.
The highest irrigation depths were applied in the first cycle of arugula cultivation, followed by the third and second cycles (Table 3). This difference in water demand is a consequence of the variation in the evapotranspiration rates occurring in the different cycles, as can be seen in Figure 1A. The results of the uniformity tests performed on irrigation systems in the cycles 1,2 , and 3 reached means of 88.3, 89.9 , and $97.0 \%$ distribution uniformity coefficient, respectively.

Table 3. Net and total irrigation depths applied in each treatment and growing season of arugula. Viçosa-MG, DEAUFV, 2016.

\begin{tabular}{|c|c|c|c|c|c|c|}
\hline \multirow{2}{*}{ Cycle } & \multirow{2}{*}{ Parâmetro } & \multicolumn{5}{|c|}{ Irrigation depth (\% ETc) } \\
\hline & & 50 & 75 & 100 & 125 & 150 \\
\hline \multirow{2}{*}{1} & Net irrigation depth (mm) & 24.68 & 37.01 & 49.35 & 61.69 & 74.03 \\
\hline & Total irrigation depth $(\mathrm{mm})$ & 27.94 & 41.92 & 55.89 & 69.86 & 83.83 \\
\hline \multirow{2}{*}{2} & Net irrigation depth (mm) & 16.09 & 24.14 & 32.19 & 40.23 & 48.28 \\
\hline & Total irrigation depth $(\mathrm{mm})$ & 17.90 & 26.85 & 35.80 & 44.75 & 53.70 \\
\hline \multirow{2}{*}{3} & Net irrigation depth (mm) & 19.68 & 29.52 & 39.37 & 49.21 & 59.05 \\
\hline & Total irrigation depth (mm) & 20.29 & 30.44 & 40.58 & 50.73 & 60.88 \\
\hline
\end{tabular}

Table 4 shows the analyses of variance for the three cycles of arugula cultivation. No single effect or interaction of cultivars and irrigation depths was observed on the root depth of arugula in the three studied cycles. Root system growth, in addition to soil moisture and cultivation, can also be affected by soil physical conditions, such as penetration resistance, and acidity and fertility in the profile. Thus, any factor not studied is restrictive and may have influenced these results. The mean depth values of the root system for the cycles 1,2 , and 3 were $18.5,17.9$, and $15.6 \mathrm{~cm}$, respectively. Cunha et al. (2013) found similar results evaluating the root depth of the cultivars Apreciata (Feltrin), Cultivada (Feltrin), and Folha Larga (TopSeed) submitted to different irrigation depths in two climate seasons of Chapadão do Sul-MS. These authors cultivated the arugula under two distinct climate seasons and did not observe the effect of the cultivars in the dry season. In the rainy season, the cultivar Folha Larga showed a higher value of root depth in relation to the others, with a difference of only $2.2 \mathrm{~cm}$. They also observed that the irrigation depths did not affect this parameter.

For root fresh mass, an isolated effect of the irrigation depths was observed in the cycle 3 . In the other crops, no single effect nor interaction of this factor was observed in the arugula cultivars (Table 4). The irrigation depths provided a linear negative effect on the root fresh mass of the arugula (Figure 2A). In addition, even the arugula with the highest root mass will have the same water and nutrient absorption capacity when submitted to lower irrigation depths since this characteristic does not increase proportionally with the increase of this factor. As new roots with a high absorption capacity are being produced, older roots become less permeable (AZIZ et al., 2017). 


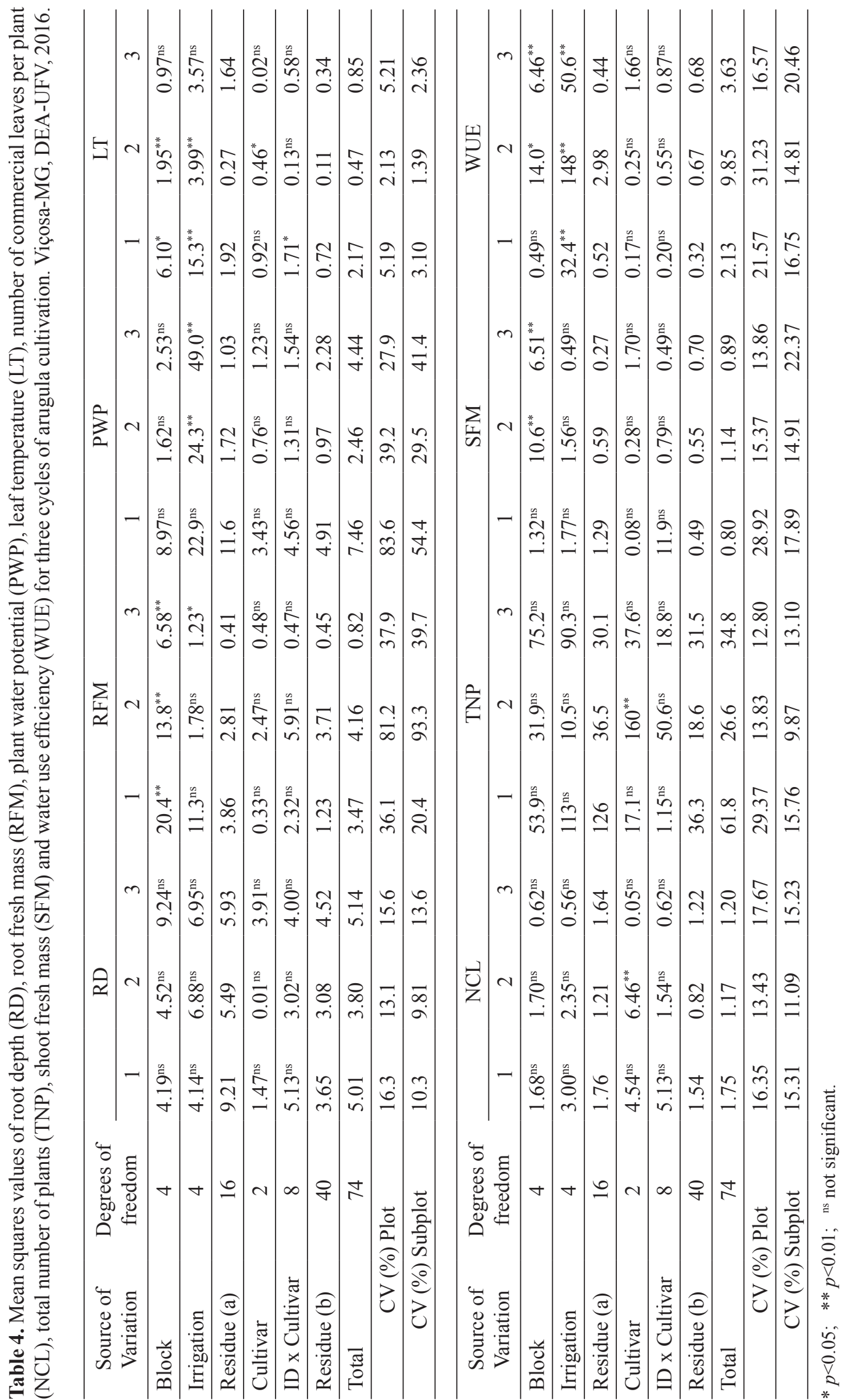


Arugula cultivars did not affect plant water potential of the evaluated cycles (Table 4), showing the same behavior for this parameter. Due to the high coefficient of variation of the plots in the cycle 1 , no effect of irrigation depths was observed on the water potential of arugula. However, in the cycles 2 and 3 , an isolated irrigation effect was observed in this parameter (Table 4). Figures $2 \mathrm{~B}$ and $2 \mathrm{C}$ show that an increase in irrigation depths provided a positive linear effect on the water potential of the cycles. This increase in water potential indicates that the arugula crop had a higher water stress in treatments that received lower irrigation depths. When plants are deficient in water, the guard cells located in the stomata have less turgidity and the stomatal opening is reduced, resulting in lower rates of $\mathrm{CO}_{2}$ absorption, leading to a reduction in the photosynthesis and in the number of new leaves, as well as leaf abscission. Thus, the physiological processes are compromised and can lead to losses in yield and product quality. Water stress causes cell dehydration, which can lead to the concentration of ions toxic to the cellular environment (TAIZ; ZEIGER, 2013).

Table 4 shows the interaction between cultivars and irrigation depths in the arugula leaf temperature in the cycle 1 . Table 5 shows that in the treatment with an irrigation depth of $50 \%$ of the ETc, the cultivar Folha Larga reached a higher value of leaf temperature in relation to the cultivar Antonella and the cultivar Cultivada did not differ from them. In the other irrigation depths, no differences in leaf temperature were observed among the evaluated cultivars.

Figure 2. Estimation of root fresh mass (RFM) in cycle 3, plant water potential (PWP) in cycles 2 and 3, leaf temperature (LT) in cycle 2 and water use efficiency in cycles 1, 2 and 3 of the arugula as a function of irrigation depths. Viçosa-MG, DEA-UFV, 2016.

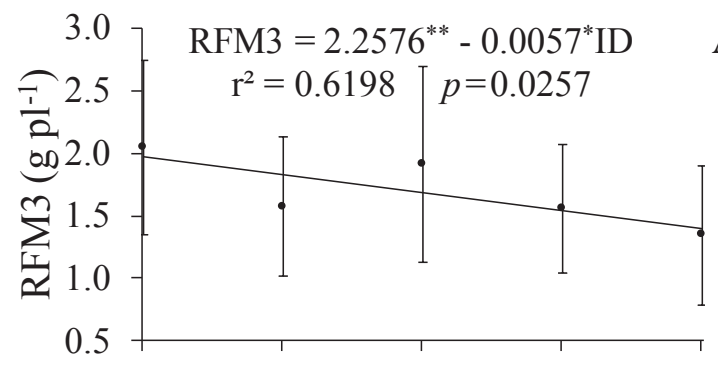

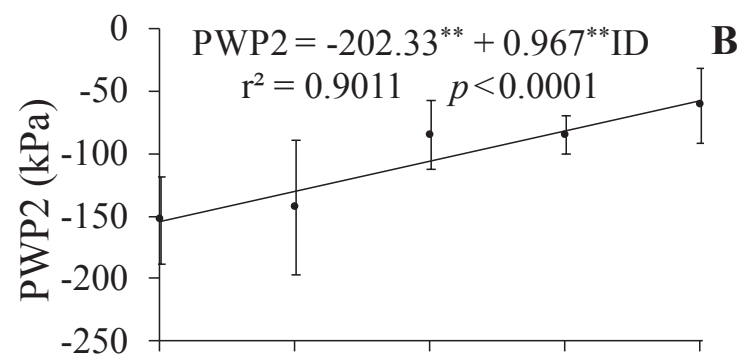

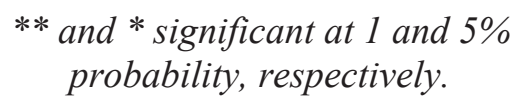

A probability, respectively.

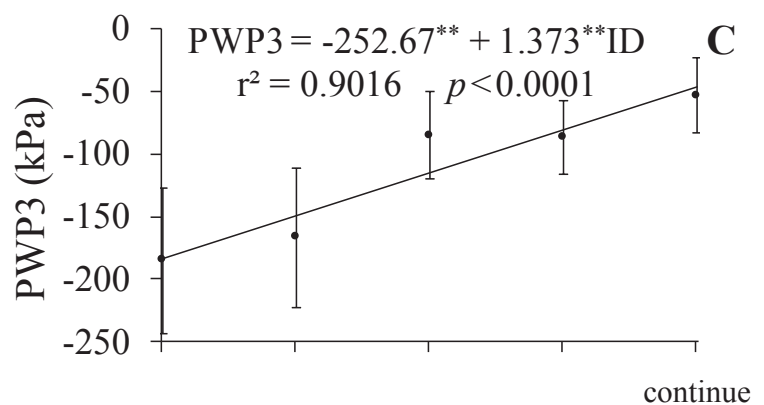


continuation
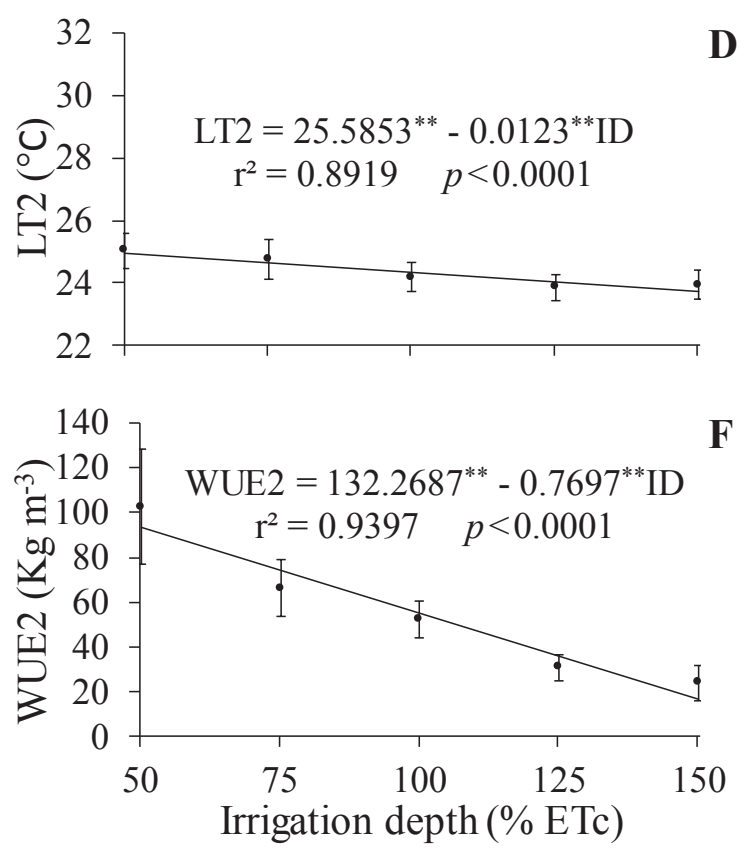

Irrigation depths provided a linear negative effect on leaf temperature of the cultivars Cultivada and Folha Larga in the cycle 1, as shown in Figures $3 \mathrm{~B}$ and $3 \mathrm{C}$, respectively. The lowest irrigation depths possibly allowed a lower water content in the plant, causing the partial closure of the stomata and reducing the loss of the latent heat caused by water vaporization, justifying the increase in leaf temperature.

In the cycles 1 and 3 , no single effect or interaction of the cultivar and irrigation depth was
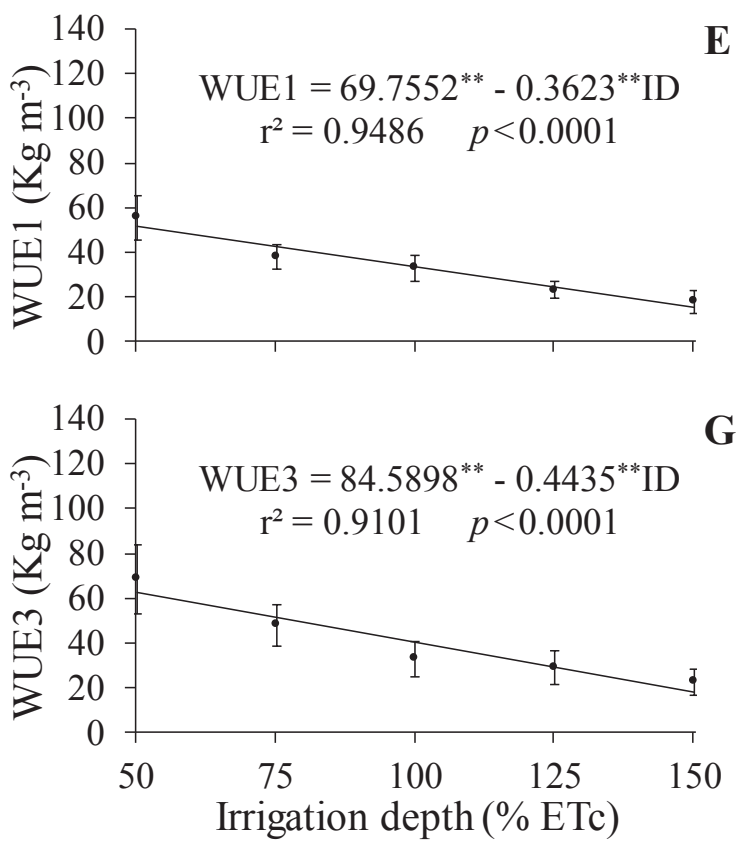

observed on the number of commercial leaves of arugula (Table 4). On the other hand, an isolated effect of the cultivars was observed in the cycle 2 , in which the cultivars Cultivada and Folha Larga did not differ from each other, but presented higher values of the number of commercial leaves in relation to the cultivar Antonella. Cunha et al. (2013) evaluated arugula cultivars in the rainy and dry seasons in Chapadão do Sul-MS and also found no difference in the number of commercial leaves in the cultivars Cultivada and Folha Larga, regardless of the season.

Table 5. Mean values of leaf temperature $\left({ }^{\circ} \mathrm{C}\right)$ as a function of different cultivars and irrigation depths in first cycle of arugula cultivation. Viçosa-MG, DEA-UFV, 2016.

\begin{tabular}{|c|c|c|c|}
\hline \multirow{2}{*}{$\begin{array}{l}\text { Irrigation } \\
\text { depth }\end{array}$} & \multicolumn{3}{|c|}{ Cultivars } \\
\hline & Antonella & Rúcula Cultivada & Folha Larga \\
\hline $50 \%$ ETc & $27.26 \mathrm{~b}$ & $28.56 \mathrm{ab}$ & $29.47 \quad \mathrm{a}$ \\
\hline $75 \%$ ETc & $27.85 \mathrm{a}$ & $28.24 \mathrm{a}$ & $28.29 \mathrm{a}$ \\
\hline $100 \%$ ETc & $27.15 \mathrm{a}$ & $27.67 \quad \mathrm{a}$ & $27.00 \quad \mathrm{a}$ \\
\hline $125 \% \mathrm{ETc}$ & $26.32 \mathrm{a}$ & $25.83 \mathrm{a}$ & $26.10 \mathrm{a}$ \\
\hline $150 \%$ ETc & $26.74 \mathrm{a}$ & $26.56 \mathrm{a}$ & $26.21 \mathrm{a}$ \\
\hline
\end{tabular}

The means followed by the same letter in each line are not significantly different using Tukey's test $(p<0.05)$. 
Figure 3. Estimation of leaf temperature (LT) in cycle 1 as a function of irrigation depths for arugula cultivars. ViçosaMG, DEA-UFV, 2016.
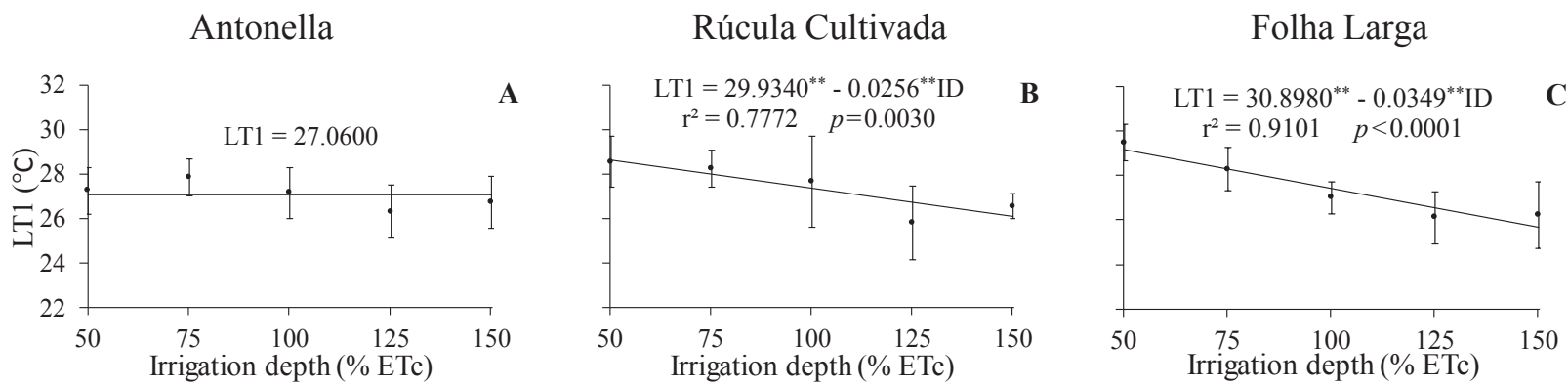

** and $*$ significant at 1 and 5\% probability, respectively.

Arugula leaf temperature was not affected by any parameter studied in the cycle 3 (Table 4 ). In the cycle 2, arugula cultivars and irrigation depths had an isolated effect on leaf temperature. The cultivar Cultivada presented a higher leaf temperature when compared to the cultivar Folha Larga and the cultivar Antonella did not differ from them in the cycle 2 (Table 6). As observed in the cycle 1, the irrigation depths provided a negative linear effect on arugula leaf temperature in the cycle 2 (Figure 2D).

Table 6. Values of leaf temperature (LT), number of commercial leaves per plant (NCL) and total number of plants (TNP) as a function of different cultivars in second cycle of arugula cultivation. Viçosa-MG, DEA-UFV, 2016

\begin{tabular}{|c|c|c|c|}
\hline Parameter & Antonella & Rúcula Cultivada & Folha Larga \\
\hline $\mathrm{LT}\left({ }^{\circ} \mathrm{C}\right)$ & $24.41 \mathrm{ab}$ & $24.46 \mathrm{a}$ & $24.20 \quad \mathrm{~b}$ \\
\hline NCL $\left(\mathrm{ud} \mathrm{pl}^{-1}\right)$ & $7.60 \quad b$ & 8.42 & $8.53 \mathrm{a}$ \\
\hline TNP $2\left(\mathrm{ud} \mathrm{m}^{-2}\right)$ & $46.60 \mathrm{a}$ & 42.40 & $42.05 \mathrm{~b}$ \\
\hline
\end{tabular}

The means followed by the same letter in each line are not significantly different using Tukey's test $(p<0.05)$.

Irrigation depths had no effect on the number of commercial leaves of arugula in the evaluated cycles. However, Moline et al. (2015) applied irrigation depths ranging from 50 to $110 \%$ of the ETc in the cultivated arugula in Vilhena-RO and found higher values of the number of commercial leaves in the treatment with an irrigation depth with 100\% ETc replacement. Vasco et al. (2011) applied different irrigation depths in the cultivar Folha Larga in Itabaiana-SE and verified that an irrigation depth of $94.9 \%$ of the ETc maximized the number of commercial leaves of arugula.

The total number of plants obtained the same behavior as the number of commercial leaves in the analysis of variance (Table 4), also showing that the irrigation depths did not have an effect on the agronomic characteristics of arugula. Table 4 shows that arugula cultivars provided an isolated effect on the total number of plants in the cycle 2 . The cultivar Antonella had a higher total number of plants when compares to the other cultivars, not differing from each other (Table 6).

No isolated effect or interaction of the factors cultivar and irrigation depth was observed on the shoot fresh mass of arugula (Table 4). This parameter is dependent on the number of commercial leaves and the total number of arugula plants. However, shoot fresh mass of arugula showed a high and 
positive correlation only with the total number of plants (Table 7). Considering the cycles 1, 2, and 3 , the mean shoot fresh mass of arugula were 1.24, 1.57 , and $1.19 \mathrm{~kg} \mathrm{~m}^{-2}$, respectively. Cunha et al. (2013) evaluated irrigated arugula cultivars in the rainy and dry seasons in Chapadão do Sul-MS and found a productivity with values close to our results. These authors found mean values of shoot fresh mass of 1.03 and $1.29 \mathrm{~kg} \mathrm{~m}^{-2}$ for the cultivars Cultivada and Folha Larga, respectively.

Table 7. Simple correlation for irrigation depth (ID), root depth (RD), root fresh mass (RFM), plant water potential (PWP), leaf temperature (LT), number of commercial leaves per plant (NCL), total number of plants (TNP), shoot fresh mass (SFM) and water use efficiency (WUE) of arugula crop. Viçosa-MG, DEA-UFV, 2016.

\begin{tabular}{|c|c|c|c|c|c|c|c|c|c|c|c|c|c|c|c|c|}
\hline & $\mathrm{RD}$ & & RFM & & PWP & & LT & & NCL & & TNP & & SFM & & WUE & \\
\hline ID & -0.0058 & ns & 0.0309 & ns & 0.5301 & ** & -0.3001 & ** & 0.0418 & ns & -0.0468 & ns & 0.0690 & ns & -0.7604 & ** \\
\hline $\mathrm{RD}$ & & & 0.2935 & ** & -0.0063 & ns & 0.2171 & ** & 0.3591 & ** & -0.2121 & ** & 0.1524 & $*$ & -0.0151 & ns \\
\hline RFM & & & & & -0.1639 & * & 0.4998 & *** & 0.1155 & ns & -0.2997 & ** & -0.0317 & ns & -0.1974 & ** \\
\hline PWP & & & & & & & -0.2246 & ** & 0.0687 & ns & -0.0021 & ns & 0.0242 & ns & -0.3640 & *** \\
\hline LT & & & & & & & & & 0.0846 & ns & -0.2087 & ** & -0.1502 & * & -0.0430 & ns \\
\hline NCL & & & & & & & & & & & -0.2246 & ** & 0.0947 & ns & -0.0381 & ns \\
\hline TNP & & & & & & & & & & & & & 0.5688 & ** & 0.2371 & ** \\
\hline SFM & & & & & & & & & & & & & & & 0.1724 & ** \\
\hline
\end{tabular}

${ }^{*} p<0.05 ; * * p<0.01 ;{ }^{\text {ns }} p>0.05$. Classification of the correlation according to Cohen (1988): as very low ( $\left.\mathrm{r}<0.1\right)$, low $(0.1<\mathrm{r}<0.3)$, moderate $(0.3<\mathrm{r}<0.5)$, high $(0.5<\mathrm{r}<0.7)$, very high $(0.7<\mathrm{r}<0.9)$, and near perfect $(\mathrm{r}>0.9)$.

The three cultivars showed similar agronomic characteristics when cultivated under the working conditions. Due to these results, the arugula cultivars Antonella, Cultivada, and Folha Larga can be indicated for cultivation in the region of the Zona da Mata of Minas Gerais. However, other studies should be carried out with the studied cultivars and others from the market for a conclusion and recommendation with a greater safety.

Irrigation depths, in general, did not have an effect on the agronomic characteristics of the arugula crop. This result is possibly due to the irrigations carried out at the beginning of the experimental period, leaving the soil with a water content equivalent to the field capacity in all treatments. By analyzing the values of field capacity, permanent wilting point (Table 1), and mean depth of the root system, we could observe that the total water capacities in the cycles 1,2 , and 3 were $33.4,32.3$, and $28.4 \mathrm{~mm}$, respectively. However, the difference between the net irrigation depth applied in the treatments of
50 and $100 \%$ of the ETc in the cycles 1,2 , and 3 (Table 3) was $24.7,16.1$, and $19.7 \mathrm{~mm}$, respectively. Therefore, in the treatments with lower irrigation depths, arugula plants possibly consumed the water retained in the soil due to irrigations performed at the beginning of the cycle, minimizing the effect of treatments of lower irrigation depths to the point of not verifying the responses of this factor in the productive parameters of the crop. In our study, this buffering effect occurred because arugula presents a short cycle and the soil of the experimental area presented a high water retention due to its high clay content, leading to a high water retention capacity (Table 1).

Although the irrigation depths did not have an effect on shoot fresh mass of arugula, some studies show different results in the literature. Vasco et al. (2011) applied different irrigation depths in the cultivar Folha Larga in Itabaiana-SE and verified that the irrigation depth that maximized the shoot fresh mass production was that restored $93.5 \%$ of the 
evapotranspirometric demand. Moline et al. (2015) verified that the irrigation depth of $100 \%$ the ETc maximized arugula yield (Cultivada) in VilhenaRO. Cunha et al. (2013) recommended to irrigate arugula plants with 50 and $125 \%$ ETc replacement in the rainy and dry seasons, respectively, of the Chapadão do Sul-MS.

An isolated effect of irrigation on water use efficiency (WUE) was observed in all arugula cycles (Table 4). Irrigation depths provided a negative linear effect in WUE by arugula (Figures 2E, 2F, and $2 \mathrm{G})$. This result was already expected since no difference was observed in the productivity of fresh leaf mass of arugula (Table 4) and WUE was a factor inversely proportional to irrigation depth. This last assertion can be proved by the negative correlation between irrigation depths and WUE, which was classified as very high (Table 7) according to Cohen (1988). Becari (2015) cultivated arugula of the cultivar Apreciata under different soil textures in a greenhouse in Botucatu-SP and also observed a linear reduction of WUE when applying irrigation depths to replenish $60,80,100$, and $120 \%$ of the field capacity. These authors also found that WUE was higher in clayey soils possibly because these soils had a higher capacity for water storage, being then provided to the crops.

The mean value of WUE for arugula was $43 \mathrm{~kg}$ $\mathrm{m}^{-3}$ when considering all the evaluated treatments and crop cycles. This result indicates that 23.2 liters of irrigation water are required to produce $1 \mathrm{~kg}$ of fresh mass of arugula leaves. Freitas et al. (2017) also verified a negative linear effect of the irrigation depths on WUE values and found an average value of $45 \mathrm{~kg} \mathrm{~m}^{-3}$ for the $100 \%$ ETc irrigation depth.

\section{Conclusions}

Arugula cultivars did not present differences in their agronomic characteristics when cultivated in the region of Zona da Mata in the State of Minas Gerais, with no recommendation of a particular cultivar for the region of study.
An irrigation depth of the $50 \%$ of the crop evapotranspiration is recommended to irrigate arugula plants if the soil moisture is under the field capacity at the beginning of their development cycle.

\section{Acknowledgments}

The authors thank Coordenação de Aperfeiçoamento de Pessoal de Nível Superior (CAPES) for granting the scholarship to the first author and financial support.

\section{References}

ALLEN, R. G.; PEREIRA, L. S.; RAES, D.; SMITH, M. Crop evapotranspiration: guidelines for computing crop water requirements. Rome: FAO, 1998. 297 p. (Irrigation and Drainage Paper, 56).

AZIZ, M. M.; PALTA, J. A.; SIDDIQUE, K. H. M.; SADRAS, V. O. Five decades of selection for yield reduced root length density and increased nitrogen uptake per unit root length in Australian wheat varieties. Plant and Soil, Dordrecht, v. 413, n. 1, p. 181-192, 2017. DOI: $10.1007 / \mathrm{s} 11104-016-3059-\mathrm{y}$

BATISTA, P. F.; PIRES, M. M. M. L.; SANTOS, J. S.; QUEIROZ, S. O. P.; ARAGÃO, C. A.; DANTAS, B. F. Produção e qualidade de frutos de melão submetidos a dois sistemas de irrigação. Horticultura Brasileira, Vitória da Conquista, v. 27, n. 2, p. 246-250, 2009.

BECARI, G. R. G. Eficiência do uso da água e parâmetros nutricionais na cultura da rúcula submetida a diferentes condições de estresse hídrico. 2015. Tese (Doutorado em Agronomia) - Universidade Estadual Paulista, Botucatu-SP.

BERNARDO, S.; SOARES, A. A.; MANTOVANI, E. C. Manual de irrigação. 8. ed. Viçosa, MG: Editora UFV, 2006. $625 \mathrm{p}$.

BORGES, C. T.; DEUNER, C.; RIGO, G. A.; OLIVEIRA, S.; MORAES, D. M. O estresse salino afeta a qualidade fisiológica de sementes de rúcula? Enciclopédia Biosfera, Goiânia, v. 10, n. 19, p. 1049-1057, 2014.

COHEN, J. Statistical power analysis for the behavioral sciences. New Jersey: Lawrence Erlbaum, 1988. 569 p.

COSTA, C. M. F.; SEABRA JÚNIOR, S.; ARRUDA, G. R.; SOUZA, S. B. S. Desempenho de cultivares de rúcula sob telas de sombreamento e campo aberto. Semina: Ciências Agrárias, Londrina, v. 32, n. 1, p. 93-102, 2011. 
CUNHA, F. F.; GODOY, A. R.; MAGALHÃES, F. F.; CASTRO, M. A.; LEAL, A. J. F. Irrigação de diferentes cultivares de rúcula no nordeste do Mato Grosso do Sul. Water Resources and Irrigation Management, Cruz das Almas, v. 2, n. 3, p. 131-141, 2013.

CUNHA, F. F.; SOUZA, I. P.; CAMPOS, W. O.; ANDRADE JÚNIOR, V. C.; MAGALHÃES, T. A.; ALEMAN, C. C. Performance of arugula genotypes under irrigation depths on Brazilian Cerrado. Ciência e Agrotecnologia, Lavras, v. 42, n. 3, p. 271-280, 2018. DOI: $10.1590 / 1413-70542018423029517$

EMPRESA BRASILEIRA DE PESQUISA AGROPECUÁRIA - EMBRAPA. Manual de métodos de análise de solo. 2. ed. Rio de Janeiro: EMBRAPA Solos, 2011. $230 \mathrm{p}$.

DOS SANTOS, H. G.; JACOMINE, P.; DOS ANJOS, L.; DE OLIVEIRA, V.; LUMBRERAS, J.; COELHO, M.; DE ALMEIDA, J.; DE ARAUJO FILHO, J.; DE OLIVEIRA, J.; CUNHA, T. Sistema brasileiro de classificação de solos. 3. ed. Rio de Janeiro: EMBRAPA Solos, 2013. 353 p.

FREITAS, E. M.; GIOVANELLI, L. B.; DELAZARI, F. T.; SANTOS, M. L.; PEREIRA, S. B.; SILVA, D. J. H. Arugula production as a function of irrigation depths and potassium fertilization. Revista Brasileira de Engenharia Agrícola e Ambiental, Campina Grande, v. 21, n. 3, p. 197-202, 2017. DOI: 10.1590/1807-1929/agriambi. v21n3p197-202
KELLER, J.; KARMELI, D. Trickle irrigation design. Glendora: Rain Bird Sprinkler Manufacturing, 1975. 133 p.

MOLINE, E. F. V.; BARBOZA, E.; STRAZEIO, S. C.; BLIND, A. D.; FARIAS, E. A. P. Diferentes lâminas de irrigação na cultura da rúcula no sul de Rondônia. Nucleus, Ituverava, v. 12 , n. 1, p. 371-378, 2015. DOI: $10.3738 / 1982.2278 .1082$

SCHOLANDER, P.F.; HAMMEL, H.T.; BRADSTREET, E. D.; HEMMINGSEN, E. A. Sap pressure in vascular plants. Science, Washington, v. 148, n. 3668, p. 339-346, 1965.

SEDIYAMA, M. A. N.; SALGADO, L. T.; PINTO, C. L. O. Rúcula. In: PAULA JÚNIOR, T. J.; VENZON, M. (Ed.). 101 culturas: manual de tecnologia agrícolas, EPAMIG. Belo Horizonte: EPAMIG, 2007. p. 53-62.

SILVA, F. A. Z.; AZEVEDO, C. A. V. The Assistat software version 7.7 and its use in the analysis of experimental data. African Journal of Agricultural Research, Lagos, v. 11, n. 39, p. 3733-3740, 2016. DOI: 10.5897/AJAR2016.11522

SYSTAT SOFTWARE, INC. SigmaPlot for Windows, version 11.0. San Jose: SSI, 2008.

TAIZ, L.; ZEIGER, E. Fisiologia vegetal. 5. ed. Porto Alegre: Artmed, 2013. 918 p.

VASCO, A. N.; AGUIAR NETTO, A. O.; MANN, R. S.; BASTOS, E. A. Irrigation management in real time for arugula crop in Sergipe. Journal of Agricultural Science and Technology, Tehran, v. 13, n. 12, p. 1161-1167, 2011. 